\title{
Taxation In Germany And Romania
}

\author{
Zhemin Wang, University of Wisconsin-Parkside, USA \\ Zhijun Lin, Hong Kong Baptist University, China \\ Yan Tan, Sun Yat-Sen University, China \\ Yuansha Li, University of Massachusetts-Lowell, USA \\ Morris Liu, Hong Kong Baptist University, China
}

\begin{abstract}
Taxation is a symbol of national sovereignty and a central part of a country's overall economic policy, helping finance public spending and redistribute wealth. Furthermore, for international business executives, taxation is an important consideration in investment decisions. This paper discusses the taxation in two European Union (EU) member countries, Germany and Romania. These two countries are selected because of their different stages of economic development and their unique characteristics in taxation.
\end{abstract}

Keywords: Taxation; European Union; Germany; Romania

\section{INTRODUCTION}

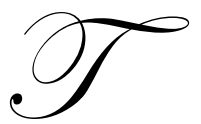

he European Union (EU) is a supranational organization founded on November 1, 1993, as the successor to the European Community (EC). In addition to taking over the economic responsibilities of the EC, the EU was also charged with forging a common foreign and security policy (CFSP) and creating closer cooperation among the EU member states in the areas of justice, home affairs, and social policy. At the time of its creation, the EU had 12 members: Belgium, Denmark, France, Germany, Great Britain, Greece, Ireland, Italy, Luxembourg, the Netherlands, Portugal, and Spain. In 1995, Austria, Finland, and Sweden were admitted. Ten more countries - eight of them from the former Communist bloc of Eastern Europe-became full members in 2004. Two additional former Communist bloc nations, Bulgaria and Romania, joined the EU in 2007, bringing the total membership to 27 nations with a combined population of 500 million and an annual gross domestic product exceeding $\$ 14.7$ trillion. While not a political federation in the strict sense, the EU is far more than a free-trade association. It has nation-like characteristics: its own executive, legislative, and judicial bodies, its own anthem and flag, a common foreign and security policy, and a common currency shared by 23 member states.

Taxation is an instrument of economic regulation which can be used to influence consumptions, encourage savings or shape the way in which companies are organized. Tax policy is a symbol of national sovereignty and a central part of a country's overall economic policy, helping finance public spending and redistribute income. The EC, the predecessor of the EU, first became involved in member states' tax policies in 1967, when it was decided that all member states should adopt a system of Value Added Tax (VAT) as part of the program to create a single market (European Commission, 2000). As a consumption tax, the EU VAT taxes the consumption of goods and services in the EU VAT area. To date, VAT remains the only EU compulsory tax for all member states. The EU has generally left the responsibility of tax policy to its member states and only plays a secondary role in taxes and social security contribution policies. Specifically, EU's role in taxation is mainly coordinating member states' tax policies to eliminate tax obstacles to cross-border activities, to prevent double taxation or unintentional non-taxation in cross-border activities, to tackle cross-border tax evasion, and to ensure no direct or indirect discrimination or restrictions to the free movement of workers, services, capital, and the freedom of establishment (European Commission, 2003).

The primary objective of the EU's tax policy is not to standardize the individual national systems of compulsory taxes and social security contributions, but simply to ensure that they are compatible with each other and with the Treaty that established the EU. The European Commission's tax policy strategy was most recently set out in a Communication on "Tax policy in the European Union - Priorities for the years ahead" (European 
Commission, 2003). The Commission in this Communication reiterated its belief that there is no need for an crossborder harmonization of member states' tax systems, and 'taxes on personal income may be left to member states even when the European Union achieves a higher level of integration than at present" (European Commission 2003, 2010). The European Court of Justice has also consistently held that taxes on personal income fall within the competence of the member states provided that they respect the fundamental Treaty principles on the free movement of workers, services, and capital and the freedom of establishment. Since EU member states are free to choose the tax systems that they consider most appropriate, it is not surprising that both the types of tax systems and the tax rates vary significantly across EU member states. This study discusses the taxation in two EU member states: Germany and Romania. These two countries are chosen in particular because Germany is a founding member and the largest economy of the EU while Romania is the newest member of the EU and a former communist country; the two countries are at different stages of economic development; and their taxation systems have some unique characteristics.

The rest of the paper is organized as follows. Section II discusses the taxation in Germany. Section III discusses the taxation in Romania. Section IV concludes the paper.

\section{TAXATION IN GERMANY}

Germany's tax-to-GDP ratio is $39.7 \%$, which is above the EU average of $35.8 \%$. However, the overall tax burden is still lower than its neighboring states of France, Austria, Denmark, and Belgium (European Commission, 2011).

Taxation in Germany is a complicated process involving 118 laws, 418 exceptions, 185 forms, and 96,000 policies (German Tax Law, 2010; Deloitte, 2011). The German tax system underwent comprehensive reforms in 2001 and 2008 to reduce the tax burden for both individuals and companies (EconomyWatch, 2011). This section briefly reviews German taxation for individuals, corporations, and foreigners, respectively.

\subsection{Individual Taxation in Germany}

Individual income taxation in Germany is progressive, with three brackets ranging from $14 \%$ to $45 \%$ (see Table 1). On top of the individual income tax, there is a Solidarity Tax of an additional $5.5 \%$ of the income tax amount. The "Solidarity Tax", a 5.5\% surcharge of the normal tax payable levied on both corporations and individuals, was introduced in 1991 and originally intended as only a one-year tax surcharge to pay for the Reunification. The Solidarity Tax is levied only on higher income tax amounts (for example, in 2010, individual income tax of up to EUR 972 is exempt from the Solidarity Tax).

Table 1: Individual Income Tax Rates in Germany ${ }^{\text {a }}$

\begin{tabular}{|c|c|}
\hline Tax Rate \% & Annual Taxable Income (EUR) \\
\hline 0 & ${\text { Up to } 8,004^{\mathrm{b}}}^{\mathrm{c}}$ \\
\hline $14 \%$ & $8,005-52,881^{\mathrm{c}}$ \\
\hline $42 \%$ & $52,882-250,730^{\mathrm{d}}$ \\
\hline $45 \%$ & 250,731 and over \\
\hline
\end{tabular}

a The rates are based on German Tax Code of 2011.

b This amount is EUR 16,008 for married couples.

c This amount is EUR 105,762 for married couples.

d The amount is EUR 501,462 for married couples.

In Germany, if an individual's income is from only one salary, he/she would not have to file an annual return. A self-employed individual is required to pay estimated tax quarterly based on the previous year's income and to file annual tax return by the end of May. In addition to income tax, the employer is required to withhold social security (i.e., the national insurance) related taxes from employees' paycheck. The rates and types of social security taxes are summarized in Table 2 . 
Table 2: Social Security Taxes in Germany ${ }^{\text {a }}$

\begin{tabular}{|l|c|c|}
\hline \multicolumn{1}{|c|}{ Component of Social Security Tax } & Tax Rate for Employee (\%) & Tax Rate for Employer (\%) \\
\hline Pension insurance & $9.95 \%$ & $9.95 \%$ \\
\hline Unemployment insurance & $1.50 \%$ & $1.50 \%$ \\
\hline Health insurance & $8.20 \%$ & $7.30 \%$ \\
\hline Nursing care insurance & $0.975 \%$ & $0.975 \%$ \\
\hline
\end{tabular}

${ }^{\mathrm{a}}$ Both the rates and the upper limits of salary are subject to each tax change over time.

German tax law allows many deductions in computing taxable income for individuals. Some of the major allowed deductions are summarized in Table 3.

Table 3: Some Allowed Deductions for Individual Income Taxation in Germany

\begin{tabular}{|l|l|}
\hline \multicolumn{1}{|c|}{ Deductible Items } & \multicolumn{1}{c|}{ Deductible Amount (EUR) } \\
\hline Donations & Deductible up to 5\% of gross income \\
\hline Business expenses & $\begin{array}{l}\text { A fixed annual EUR 920 is allowed without documentation (a higher amount } \\
\text { may be requested with documentation) }\end{array}$ \\
\hline Child allowance & EUR 1,824 per child. Additional EUR 1,000 for child under 14 years of age \\
\hline Life insurance payments & Deductible up to a limit \\
\hline Alimony & Up to EUR 13,805 per year \\
\hline Church tax & Fully deductible \\
\hline Expenses for traveling to and from work & Up to EUR 4,500 per year \\
\hline Professional Travel & Fully deductible \\
\hline Home Office & Up to EUR 1,250 per year \\
\hline
\end{tabular}

In Germany both inheritances and gifts are subject to taxation. When either the person making the gift (the testator) or the recipient of the gift (the heir) is a German resident, the tax applies also to assets that are overseas. When neither the person making the gift nor the recipient of the gift is a German resident, the tax applies only to assets that are located in Germany (Federal Ministry of Finance, 2007). When tax is imposed on assets in a foreign country, the tax paid overseas will be deducted from the tax payable in Germany. For these purposes a Double Taxation Prevention Treaty has been signed with a number of countries, including the United States of America, Switzerland, and Austria, to name a few. Recipients of gifts and inheritances are divided into three groups: spouse, children, parents and grandchildren, and all others. The tax rates vary from $7 \%$ to $50 \%$, depending on the group and also on the value of the asset.

Since 2009, in Germany, capital gains are taxed at a flat rate of 25\%. However, capital gains from selling real property held for more than 10 years are exempt from capital gains tax. Capital gain from selling investment in another company is taxed at the regular flat rate of $25 \%$ if the ownership percentage is less than $1 \%$. In cases when ownership is greater than $1 \%$, only $60 \%$ of the capital gains are subject to taxation at the regular rate.

\subsection{Corporate Taxation in Germany}

In Germany businesses are usually organized in one of the following forms: Limited Liability Company, Stock Company, Regular Partnership, and Limited Partnership. A partnership is not a separate body for tax purposes. The income from the partnership is divided between the partners who will then each pay his/her tax as an individual.

The effective corporate income tax rate in 2011 is $30-33 \%$, including federal corporate income tax, municipality's "business tax," and the Solidarity Tax. German federal corporate income tax is a flat $15 \%$. The "business tax" payable to the municipality is $14-17 \%$. A company that operates in a number of cities pays business tax according to the location of its employees in the various cities. "Business tax" is deductible for calculating taxable income for federal corporate income tax. 95\% of the capital gain from the sale of shares in another company is exempt from tax when received by a company in Germany. Companies are required to make quarterly estimated tax payments on the 10th day of the months of March, June, September, and December. An annual tax return must be filed by May 31 of the following year. A fine of $1 \%$ per month is assessed on tax in arrears. 
Depreciation expense can be computed using either the straight-line or the depreciated balance method. When the depreciated balance method is used, the depreciation cannot exceed $20 \%$ or twice the straight-line rate. For plant assets acquired after January 1, 2008, they must be depreciated using the straight-line method. The depreciation rates for selected plant assets are summarized in Table 4.

Table 4: Depreciation Rates for Selected Assets

\begin{tabular}{|l|c|}
\hline \multicolumn{1}{|c|}{ Types of Assets } & Annual Depreciation Rate (\%) \\
\hline Aircraft & $5 \%$ \\
\hline Vehicles & $16.6 \%$ \\
\hline Computers & $33.3 \%$ \\
\hline Office Equipment & $6 \%-14 \%$ \\
\hline Machinery and Equipment & $6 \%-10 \%$ \\
\hline
\end{tabular}

Value Added Tax (VAT) of $19 \%$ is imposed on products and services in Germany as well as on imports into Germany. There is a reduced rate of $7 \%$ for food and agricultural products. Exports are exempt from VAT. VAT reports must be filed monthly. Similar to a sale tax, the VAT is ultimately born by consumers. Corporate taxation issues related to net operating loss carry backs and carry forwards, related party transactions, tax consolidation, and financing expenses are summarized in Table 5.

Table 5: Selected Corporate Taxation Issues

\begin{tabular}{|l|l|}
\hline \multicolumn{1}{|c|}{ Corporate Taxation Issues } & \multicolumn{1}{c|}{ Tax Treatment } \\
\hline $\begin{array}{l}\text { Net operating loss carry backs } \\
\text { and carry forwards }\end{array}$ & $\begin{array}{l}\text { Loss up to EUR 1 million can be offset forward in one year. Loss above this amount can be } \\
\text { offset against 60\% of the current year taxable income. } \\
\text { Loss can be carried back one year. }\end{array}$ \\
\hline Related party transactions & $\begin{array}{l}\text { Related party transactions are closely monitored by the tax authorities and are compared to } \\
\text { accepted market prices. }\end{array}$ \\
\hline Consolidated statements & $\begin{array}{l}\text { The parent company may file consolidated tax returns so losses of one subsidiary can offset } \\
\text { profits from other subsidiaries. }\end{array}$ \\
\hline Financing expenses & $\begin{array}{l}\text { Interest is deductible up to 30\% of the income before interest, depreciation and loss carry } \\
\text { forward (the limitation does not apply to interest expense of up to EUR 1 million). }\end{array}$ \\
\hline
\end{tabular}

\subsection{Taxation for Foreigners in Germany}

Foreigners in Germany are taxed on their German source income only if they are non-residents for tax purposes, and are taxed on their worldwide income if they meet the resident requirement for tax purposes. A foreigner is considered a tax resident in Germany if one of the following two conditions is met: (1) his/her life is centered in Germany, or (2) he/she stays in Germany for six months during two tax years.

Under German tax law, deductions at source must be made from the following payments to nonresidents:

- $\quad$ Dividend - 21.1\%. (Including solidarity tax).

- $\quad$ Royalties $-15.825 \%$ (including solidarity tax).

- Interest - $0 \%$.

The above withholding taxes are subject to Double Taxation Prevention Treaties.

\section{TAXATION IN ROMANIA}

The overall tax-to-GDP ratio of Romania is $27 \%$, which is nine percentage points lower than the EU average of $35.8 \%$ (European Commission, 2011). The level of taxation in Romania is the lowest in the EU. In addition, the tax structure of Romania relies heavily on indirect taxes $(40.9 \%)$ and social security contributions $(24.2 \%)$, and less on direct taxes $(24.8 \%)$. Romania's currency is currently the New Leu (RON). The Romanian government plans to adopt the Euro in 2014. 
In Romania, major business forms include:

- $\quad$ Limited Liability Company (SRL). One person, legal or natural, is sufficient to set up a limited liability company. The maximum number of shareholders in a SRL is 50. The minimum registered capital is RON 200 with a minimum par value of RON 10 per share. Shareholders' liabilities are limited to the amount of their capital investment.

- Joint Stock Company (SA). This entity is similar to SRL but for larger companies. It requires a minimum of two natural or legal persons, and requires a minimum registered capital of RON 90,000 with a minimum par value of RON 0.1 per share.

- $\quad$ General Partnership (SNC). All partners are jointly and severally liable for partnership liabilities.

- $\quad$ Partnership Limited by Shares (SCA). The liability of limited partners is limited to their investment in the partnership. However, there must be at least one partner with unlimited liability.

- Branch. Foreign companies are allowed to establish a branch office in Romania. The branch office can only operate in the same activities of its parent company.

- $\quad$ Representative Office. The representative office is not allowed to commit in legal engagement, but instead is used as a first step for exploring future business activities in Romania.

One major difference between taxation in Germany and Romania is Romania's flat tax. The Truth and Justice Alliance won the Romanian presidential election in 2004 and subsequently introduced the $16 \%$ flat tax system in 2005 (Paraipan, 2005). The 16\% flat rate applies to both corporate income and personal income. The flat tax replaced the five personal income tax brackets ranging from $18 \%$ to $40 \%$ and the corporate income tax rate of 25\%. The International Monetary Fund called Romania's flat tax "a good fiscal policy." Proponents of the flat tax system suggest that the flat tax system reduces tax evasion, is easy to administer, and encourages economic activity. However, its critics argue that it is a regressive tax system.

\subsection{Romania Corporate Taxation}

Romania's corporate tax rates are summarized in Table 6.

Table 6: Romanian Corporate Tax Rates

\begin{tabular}{|l|c|}
\hline \multicolumn{1}{|c|}{ Taxable Item } & Applicable Tax Rate \\
\hline Corporate income & $16 \%$ \\
\hline Capital gain & $16 \%^{\text {a }}$ \\
\hline Net operating losses carry back & Not allowed \\
\hline Net operating losses carry forward & 7 years \\
\hline
\end{tabular}

${ }^{a}$ Only non-resident entities are taxed for capital gains.

Taxable income is the difference between taxable revenues and expenses. Dividends received from another Romanian company are not included in the computation of taxable revenue. Tax deductible expenses include, but are not limited to, the following: advertising and other marketing expenses, travel expenses (up to 2.5 times of the ceiling set for public institutions), entertainment expenses (up to $2 \%$ of taxable income), employee training expenses, environment protection expenses, bad debts expenses, and depreciation expenses (Deloitte, 2011). In Romania, taxable depreciation expenses can be computed using one of the three methods: straight-line, reduced balance depreciation, and accelerated depreciation. Buildings must be depreciated using the straight-line method. The government sets useful lives for different types of assets (e.g., 8 to 60 years for buildings and 2 to 24 years for equipment). The company is allowed to choose a useful life within the interval set by the government.

\subsection{Romania Individual Taxation}

In accordance with the flat tax, Romania's individual income tax rate is $16 \%$ on all personal income. For Romanian and foreigners meeting the resident criteria for three consecutive years, a personal deduction of RON 250 is allowed for individuals earning up to RON 1,000 (about \$339) per month with no dependents. The deduction is 
RON 650 for individuals earning up to RON 1,000 per month with four or more dependents. The deduction is phased out entirely for individuals whose monthly income is RON 3,000 or above (Ernst \& Young, 2010). In addition, the following are deductible in computing employment income: social security contributions, pension contributions, and union dues.

The standard VAT rate in Romania is $19 \%$. There is a reduced VAT rate of $9 \%$. The reduced VAT rate applies to hotel services, books, newspapers, and medicines. Insurance companies, banks and financial services in Romania are exempt from VAT. The fiscal period for VAT is the calendar quarter. The VAT return must be filed by the 25th of the month following the quarter. VAT registration is compulsory when the annual turnover for the previous year is above EUR 100,000.

Romania's social security tax rates are summarized in Table 7.

Table 7: Romanian Social Security Tax Rates

\begin{tabular}{|l|c|c|}
\hline \multicolumn{1}{|c|}{ Social Security Tax Component } & Tax Rate for Employer & Tax Rate for Employee \\
\hline Social Security & $20.8 \%-30.8 \%$ & $10.5 \%$ \\
\hline Health Fund & $5.2 \%$ & $5.5 \%$ \\
\hline Unemployment Fund & $0.5 \%$ & $0.5 \%$ \\
\hline Risk Fund & $0.15 \%-0.85 \%$ & - \\
\hline Labor Chamber & $0.25 \%-0.75 \%$ & - \\
\hline
\end{tabular}

Romanian tax law imposes building tax and land tax. The standard building tax for buildings located in Romania is $0.1 \%-0.2 \%$ for individuals and $0.5 \%-1 \%$ for legal entities. For buildings which were bought more than 3 years before the current tax year, without being revaluated for 3 years, the tax rate for legal entities is $5 \%$ $10 \%$ of the book value. Land tax is imposed on land located in Romania. The tax is levied as a lump sum per meter, depending on the land's location and use.

\subsection{Romania Taxation for International Investors}

Under Romanian tax law, resident companies and individuals are taxed on their Romanian and worldwide income while non-resident companies and individuals are taxed on Romania source income. A foreign company is considered a resident company if its headquarters (or its place of effective management) is in Romania. A foreigner is considered a Romania tax resident if his/her center of living is in Romania or if he/she stays in Romania for at least 183 days during a calendar year. If a foreigner meets the tax resident rule for three consecutive years, he/she will be subject to Romanian tax on worldwide income starting from the fourth year. For multinational corporations in Romania, transfer pricing must be based on the arm's length principle where the market value is determined by comparable uncontrolled price method, the cost plus method, the resale price method, or any other methods recognized by the Organization of Economic Cooperation and Development (OECD) (KPMG, 2011).

Romanian withholding tax is summarized in Table 8 (PriceWaterhouseCoopers, 2009, 2011). In Romania, companies are required to remit withholding tax to the State by $25^{\text {th }}$ of the following month after the payment was made and are required to file an annual withholding tax return by June $30^{\text {th }}$ of the following year.

Table 8: Romanian Withholding Tax Rates ${ }^{\text {a }}$

\begin{tabular}{|l|c|}
\hline \multicolumn{1}{|c|}{ Type of Payments } & \multicolumn{1}{c|}{ Withholding Tax Rates (\%) } \\
\hline Interest & $16 \%^{\mathrm{b}}$ \\
\hline Royalties & $16 \%^{\mathrm{b}}$ \\
\hline Dividends & $16 \%^{\mathrm{c}}$ \\
\hline Commissions and services & $16 \%$ \\
\hline
\end{tabular}

a Romania signed over 85 treaties for the prevention of double taxation. The withholding tax rate may be reduced by the applicable double taxation prevention treaties.

$\mathrm{b}$ Interest and royalties may be exempt from withholding tax if the payee is an EU legal entity and owns more than $25 \%$ of the Romanian company for more than two years consecutively. Interest paid to EU resident individuals is exempt from Romanian withholding tax under certain conditions.

c This rate is $10 \%$ if the payee is an EU legal entity. 
Most of the tax incentives for foreign investors were withdrawn after Romania joined the EU in 2007, with the exception of the profit reinvestment whereas profit reinvested by the taxpayer is exempt from income tax (Worldwide Tax, 2011). The profit must be reinvested in the production and/or acquisition of technological equipment and, furthermore, such equipment must be maintained in production for at least half of the asset's useful life.

\section{CONCLUDING REMARKS}

Our brief discussion of taxation policies in two EU member states shows that each country has its unique tax regulation. The two EU member states have very different rates for business tax, personal tax and VAT. These differences reflect the different economic priorities of the two countries: Romania seeks to lower taxes to encourage enterprise activities and to attract foreign investments while Germany seeks higher taxes to pay for its welfare and healthcare.

As discussed in Section 1, EU member countries retain control over their own tax systems. The EU's role is primarily the coordination of tax policies of its member states to prevent harmful tax competition between member states and to support the principle of free movement of labor and capital (European Commission, 2010, 2011). In the past, some member states offered excessive tax incentives to attract foreign investment, sometimes at the expense of other EU countries where the investment was economically more justified. EU member states are now bound by a Code of Conduct to prevent this from recurring. They are phasing out harmful tax breaks inherited from the past. There are also EU rules and codes of conduct to ensure comparable tax treatment of cross-border payments of interest, royalties, and dividends to sister and parent companies and of cross-border intra-company sales of goods and services (i.e., transfer prices) in all member states. The EU Commission has taken steps to ensure that all member states take the same approach to taxing groups of companies. There is also discussion on having a common tax base so rules applying to each type of transactions would be the same across the EU in order to prevent unfair competition (European Commission, 2011). However, actual tax rates remain a matter for member states. Personal taxation rules and rates are also matters for member states, unless the EU sees the need to step in to prevent discrimination against working or investing in another country. The EU has also taken actions to ensure that EU citizens are not deterred from working in other EU countries for tax reasons.

While EU citizens can place their savings where they think they will get the best return, taxes remain due in their country of residence. EU governments lose legitimate revenue if their residents do not declare interest income on savings held abroad. As a remedy, EU member states have been exchanging information on non-residents' savings since July 1, 2005. On VAT, the EU has a strong interest in co-coordinating policy not only to promote a single market but also because some of the money that goes into the EU budget is based on member states' VAT systems (Bettendorf et al., 2011; European Commission 2010). The EU taxation policy ensures that tax rules in its member states are consistent with the goals of job creation, the EU's competitiveness, the single market, and free movement of capital.

Our discussion on taxation in Germany and Romania intends to give a general introduction of the tax systems in the two countries to help investors become familiar with the taxation in these countries. Companies and individuals interested in investing in these two countries should consult a tax accountant/attorney for matters related to taxation.

\section{ACKNOWLEDGMENT}

Helpful comments from the participants of the 2010 International Business and Economics Research Conference in Las Vegas and the participants of the American Accounting Association (AAA) 2010 Annual Meeting in San Francisco on earlier versions of this manuscript are gratefully acknowledged. 


\section{AUTHOR INFORMATION}

Zhemin Wang received his Ph.D. in accounting from the University of Wisconsin-Madison, Madison, WI, USA, in 1991. He has taught financial accounting, managerial accounting, and international accounting at both graduate and undergraduate levels for 20 years at North Dakota State University (1991-1998) and the University of WisconsinParkside (1998-present). He is currently a professor of accounting and the director of global education at the School of Business and Technology, University of Wisconsin-Parkside. Professor Wang's research interest is international accounting and financial reporting, and has published over 50 journal articles and referred conference proceedings. Professor Wang has been nominated for numerous teaching honors and awards. He was the "Teacher of the Year" of the College of Business Administration at North Dakota State University in 1997, and won University of Wisconsin-Parkside’s “Stella Gray Distinguished Teaching Award” in 2008. E-mail: wangz@uwp.edu. Corresponding author.

Zhijun Lin, Hong Kong Baptist University, E-mail: zjlin@hkbu.edu.hk

Yan Tan, Sun Yat-Sen University, E-mail: mnstjs@mail.sysu.edu.cn

Dr. Annie Yuansha Li is an Assistant Professor at University of Massachusetts Lowell. Prior to that, she was a tenure-track faculty at University of Wisconsin-Parkside. She had been a CPA with KPMG and Associate Director for a NYSE listed company before entering into academia. Her scholarship includes work in corporate governance and accounting information in global capital markets. E-mail: yuansha_li@uml.edu

Morris Liu, Hong Kong Baptist University, E-mail: mliu@hkbu.edu.hk

\section{REFERENCES}

1. Bettendorf, L., Devereux, M.P., Loretz, S. and Horst, A. "Corporate Tax Reform in the EU: Weighing the Pros and Cons.” Vox, March 2011 (http://www.voxeu.org/index.php?q=node/6248).

2. Deloitte, Taxation and Investment Guide: Germany, 2011

3. Deloitte, Taxation and Investment Guide: Romania, 2011

4. EconomyWatch, Taxation in Germany, 2011

5. $\quad$ Ernst \& Young, Taxation in Romania, Feb. 2010.

6. European Commission, The Reform of Taxation in EU Member States: Final Report for the European Parliament, Tender No. IV, May 2000.

7. European Commission, Tax Policy in the European Union - Priorities for the Years Ahead, 2001.

8. European Commission, "A Common System of Taxation Applicable to Interest and Royalty Payments Made Between Associated Companies of Different Member States," Council Directive, June 2003.

9. European Commission, Tax Reform: Increasing Revenue without Compromising Growth, European Economy News, Issue 19, October 2010.

10. European Commission, Tax Trend in the European Union, 2011 (http://ec.europa.eu/taxation_customs/taxation/gen_info/economic_analysis/tax_structures/index_en.htm).

11. Federal Ministry of Finance (German), Information about Inheritance and Gift Tax, 2007 (http://www.bundesfinanzministerium.de/EN/Home/node.html? nnn=true).

12. German Tax Law (http://en.wikibooks.org/wiki/German_Tax_Law).

13. KPMG, A World in Transition: Managing the Transfer Pricing Implications of Complex Supply Chains, August, 2011.

14. Paraipan, M., "Romania's New Flat Tax.” Global Politian, Feb. 2005.

15. PriceWaterhouseCoopers, EU Tax News, 2009.

16. PriceWaterhouseCoopers, The Romania Tax Pocket Book, 2011.

17. Worldwide Tax, 2011 (www.worldwide-tax.com). 